\title{
Upaya Peningkatan Hasil Belajar Melalui Model Pembelajaran Kooperatif Tipe Jigsaw Berbantu Media Gambar
}

\author{
Azin Trihartoto ${ }^{1 *}$ \\ ${ }^{1}$ PGSD FKIP Universitas Kristen Satya Wacana
}

\author{
ARTICLEINFO \\ Article history: \\ Received 18 Desember \\ 2019 \\ Received in revised form \\ 30 Desember 2019 \\ Accepted 15 Januari 2020 \\ Available online 20 \\ Februari 2020 \\ Kata Kunci: \\ Model kooperatif, Jigsaw, \\ Media Gambar, Hasil \\ Belajar. \\ Keywords: \\ Cooperative Model, \\ Jigsaw, Image Media, \\ Learning Outcomes
}

\begin{abstract}
A B S T R A K
Tujuan dari penelitian ini untuk meningkatkan hasil belajar siswa kelas IV SDN Dukuh 2 Salatiga. Subjek pada penelitian ini adalah siswa kelas IV SDN Dukuh 2 Salatiga dengan jumlah siswa ada 30. Rancangan atau desain penelitian tindakan kelas (PTK) yang digunakan peneliti adalah menggunakan model PTK Kemmis dan Mc Taggart yang terdiri dari empat tahap yaitu perencanaan, aksi atau tindakan, observasi, serta refleksi. Metode pengumpulan data dengan menggunakan tes untuk mengetahui hasil belajar dan lembar observasi untuk mengetahui aktivitas keterlaksanaan pembelajaran guru dan siswa. Data diperoleh kemudian diolah secara kuantitatif kemudian dianalisis secara kualitatif berupa kategori pada setiap rentang yang diperoleh. Perolehan data didapatkan dari tiga kegiatan yaitu pra siklus, siklus I dan siklus II. Hasil perolehan data ketuntasan belajar mengalami peningkatan yaitu pada pra siklus KD 3.9 sebesar 46\%, siklus I meningkat menjadi 76,7\%, siklus II meningkat menjadi 90\%. Slanjutnya untuk KD 3.4 pada pra siklus sebesar $36,7 \%$, siklus I meningkat menjadi $73,3 \%$, siklus II meningkat menjadi $83,3 \%$. Berdasarkan hasil data yang diperoleh membuktikan bahwa penerapan model pembelajaran Kooperatif tipe Jigsaw berbantu media gambar khususnya untuk tema 8 "Tempat Tinggalku" benar adanya bisa meningkatkan hasil belajar siswa kelas IV SDN Dukug 2 Salatiga.
\end{abstract}

\section{A B S T R A C T}

The purpose of this study was to improve student learning outcomes in grade IV SDN Dukuh 2 Salatiga. The subjects in this study were students in grade IV SDN Hamlet 2 Salatiga with a total of 30 students. The design of the classroom action research (CAR) used by researchers was to use a PTK Kemmis and Mc Taggart model consisting of four stages: planning, action or action, observation, and reflection. Methods of data collection using tests to determine learning outcomes and observation sheets to determine the implementation of learning activities of teachers and students. The data obtained is then processed quantitatively then analyzed qualitatively in the form of categories in each range obtained. Data obtained from three activities, namely precycle, cycle I and cycle II. The results of learning completeness data acquisition increased, namely in the precycle KD 3.9 of 46\%, the first cycle increased to $76.7 \%$, the second cycle increased to $90 \%$. Next to KD 3.4 in the precycle of $36.7 \%$, the first cycle increased to $73.3 \%$, the second cycle increased to $83.3 \%$. Based on the results of the data obtained prove that the application of the Jigsaw Cooperative learning model assisted with the media image, especially for the theme 8 "Where I Stay" really can improve student learning outcomes in grade IV SDN Dukug 2 Salatiga.

Copyright (C) Universitas Pendidikan Ganesha. All rights reserved.

\section{Pendahuluan}

Pendidikan merupakan salah satu bagian yang penting untuk mempersiapkan sumber daya manusia dalam kemajuan bangsa. Undang-Undang No.20 Tahun 2003 menyebutkan pendidikan nasional berfungsi mengembangkan kemampuan dan membentuk watak serta peradaban bangsa yang bermartabat dalam rangka mencerdaskan kehidupan bangsa, bertujuan untuk berkembangnya potensi peserta didik agar menjadi manusia yang beriman dan bertakwa kepada Tuhan Yang Maha Esa, berakhlak mulia, sehat, berilmu, cakap, kreatif, mandiri dan menjadi warga negara yang demokratis serta bertanggung jawab.

\footnotetext{
${ }^{1}$ Corresponding author.

E-mail addresses: 292019705@student.uksw.edu(Azin)
} 
Menurut UU No. 14 tahun 2005, guru yang merupakan pendidik profesional dengan tugas utama mendidik, mengajar, membimbing, mengarahkan, melatih, menilai, dan mengevaluasi peserta didik pada pendidikan anak usia dini jalur pendidikan formal, pendidikan dasar, dan pendidikan menengah. Guru juga merupakan faktor penting dalam meningkatkan hasil belajar murid, salah satunya dalam penggunaan metode pembelajaran yang tepat pada setiap materi yang disampaikan. Untuk mencapai keberhasilan guru harus dapat merubah paradigma pendidikan yang ada dari pembelajaran yang berpusat pada guru diubah menjadi berpusat kepada siswa.

Berdasarkan hasil observasi yang dilakukan di kelas IV SD Negeri Dukuh 2 Kota Salatiga, hasil pembelajaran terbukti selalu kurang memuaskan. Hampir dari keseluruhan siswa, kurang dari $50 \%$ siswa yang mancapai ketuntasan KKM 70. Selain itu banyak kendala yang dialami oleh siswa diantara siswa tidak nyaman atau tidak antusias dengan metode mengajar yang digunakan. Guru cenderung menggunakan metode ceramah, sehingga siswa hanya diam mendengarkan materi yang disampaikan guru, siswa kurang aktif, serta ada yang siswa yang cerita dan bermain-main sendiri saat proses pembelajaran berlangsung.

Salah satu model pembelajaran yang dapat meningkatkan siswa belajar secara optimal adalah model pembelajaran kooperatif tipe jigsaw. Hal ini didukung oleh pendapat Rusman (2013: 115) bahwa tipe jigsaw adalah model pembelajaran yang meningkatkan kerja sama antar siswa, memiliki banyak kesempatan untuk mengemukakan pendapat serta meningkatkan rasa tanggung jawab siswa terhadap pembelajarannya sendiri dan juga pembelajaran orang lain. Upaya lain untuk meningkatkan hasil belajar dan menambah keaktifan siswa adalah dengan penggunaan media dalam proses pembelajaran. Media pembelajaran dapat membantu siswa untuk lebih memahami materi yang disampaikan oleh guru. Media juga dapat diartikan sebagai sarana atau alat bantu yang berguna dalamproses pembelajaran, salah satu media yang dapat diterapkan yaitu media gambar. Media gambar merupakan salah satu benda konkret yang dapat dilihat dan diamati oleh siswa. Oleh sebab itu, dengan menggunakan media pembelajaran akan memudahkan siswa untuk memahami materi pelajaran.

Berdasarkan permasalahan yang didapat oleh peneliti, penelitian ini memiliki tujuan yaitu : "Untuk meningkatkan hasil belajar siswa kelas IV SD Negeri Dukuh 2 Salatiga melalui model pembelajaran kooperatif tipe Jigsaw berbantu media gambar".

\section{Metode}

Rancangan atau desain penelitian tindakan kelas (PTK) yang digunakan peneliti adalah menggunakan model PTK Kemmis dan Mc. Taggart. Model yang dikembangkan oleh Kemmis dan Mc. Taggart tampak masih begitu dekat dengan model yang diperkenalkan oleh Kurt Lewin. Dikatakan demikian karena didalam satu siklus terdiri dari empat komponen seperti halnya yang dilaksanakan oleh Kurt Lewin sehingga belum tampak adanya perubahan. berikut keempat komponen tersebut meliputi perencanaan (Planning), aksi atau tindakan (Acting), observasi (Observing), refleksi (Reflecting). Hanya saja sesudah siklus selesai diimplementasikan, khususnya sesudah adanya refleksi, kemudian diikuti dengan adanya perencanaan ulang yang dilaksanakan dalam bentuk siklus tersendiri (Aqib, 2006:22).

Subjek yang diambil oleh peneliti adalah siswa kelas IV yang berjumlah 30 siswa terdiri dari 17 laki-laki perempuan dan 13 siswa perempuan. Teknik pengumpulan data yakni cara yang digunakan untuk mengumpulkan atau memperoleh data dalam satu penelitian. Adapun teknik pengumpulan data yang peneliti gunakan melalui teknik observasi dan teknik tes.

\section{Hasil dan Pembahasan}

Penelitian tindakan kelas (PTK) memiliki banyak model, sehingga peneliti dapat memiliki salah satu model yang sesuai dengan yang dikehendaki. Ada beberapa macam model pelaksanaan penelitian tindakan kelas (PTK) yang dikembangkan oleh beberapa ahli, akan tetapi yang paling terkenal didunia pendidikan terdapat lima model yaitu: Model Lewin, Model Mc. Kernan, model Ebbut, Model Elliot dan model Kemmis dan Mc Taggart. Berdasarkan jenis penelitian sebagaimana dipaparkan sebelumnya, rancangan atau desain penelitian tindakan kelas (PTK) yang digunakan peneliti adalah menggunakan model PTK Kemmis dan Mc. Taggart. Adapun tujuan dari penelitian ini adalah Untuk meningkatkan hasil belajar siswa kelas IV SD Negeri Dukuh 2 Salatiga melalui model pembelajaran kooperatif tipe Jigsaw berbantu media gambar pada tema 8 "Tempat 
Tinggalku". Penelitian ini dilakukan di kelas SD Negeri Dukuh 2 yang terletak di Kelurahan Dukuh, Kecamatan Sidomukti, Kota Salatiga, Jawa Tengah. Penelitian dilaksanakan sebanyak 2 kali pertemuan dalam setiap siklus dengan menyesuaikan jadwal. Subjek yang diambil oleh peneliti adalah siswa kelas IV yang berjumlah 30 siswa terdiri dari 17 laki-laki perempuan dan 13 siswa perempuan. Kemampuan masing - masing siswa heterogen. Penelitian ini terdiri atas dua siklus, yaitu Siklus I dan Siklus II. Yang akan dijabarkan sesuai dengan tabel dibawah ini.

Tabel 01 Hasil Penilaian Presentasi Siklus I

\begin{tabular}{|c|c|c|}
\hline Aspek & Rata-rata (\%) & Kriteria \\
\hline Intonasi & $70 \%$ & Baik \\
\hline Bahasa & $70 \%$ & Baik \\
\hline Volume Suara & $80 \%$ & Baik \\
\hline
\end{tabular}

Berdasarkan tabel 01 di atas dapat dillihat hasil penilaian presentasi hasil diskusi kelompok pada siklus I diketahui bahwa rata-rata intonasi siswa sebesar 70\% dengan kriteria baik, rata-rata bahasa siswa sebesar 70\% dengan kriteria sangat baik, serta rata-rata volume suara siswa sebesar $80 \%$ dengan kriteria baik. Hasil penilaian presentasi hasil diskusi kelompok pada siklus I ini juga dapat disajikan dalam bentuk diagram yang dapat dilihat pada gambar 01 berikut:

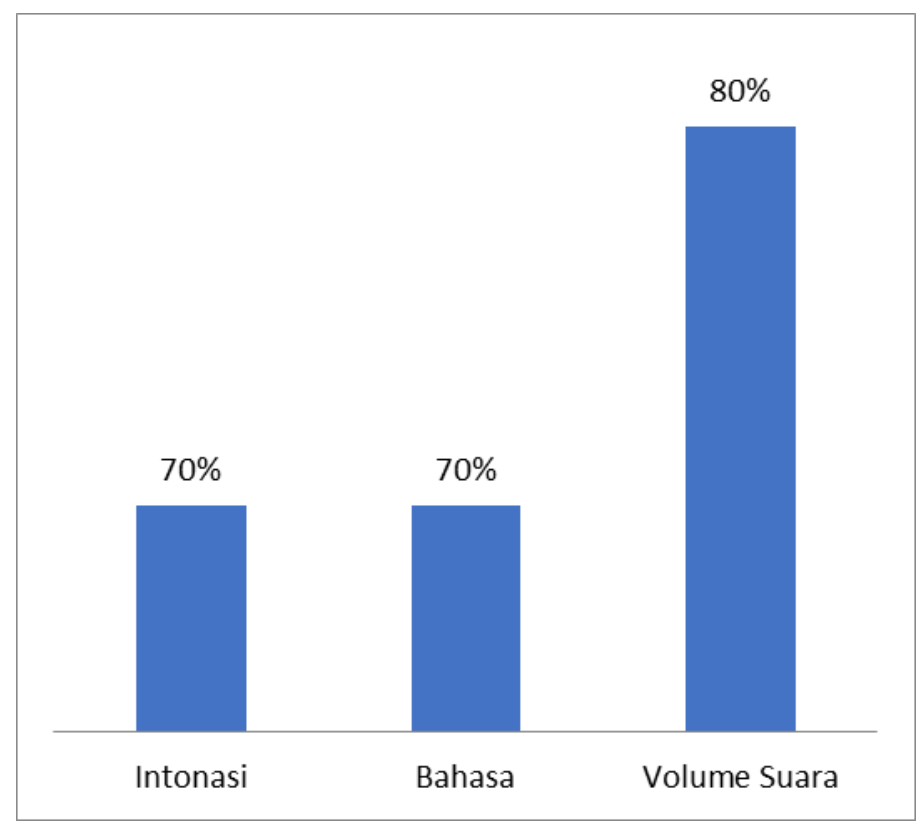

Gambar 01 Diagram Hasil Penilaian Presentasi Kelompok Siklus I berikut:

Kemudian untuk hasil belajar pada aspek pengetahuan juga dapat dilihat melalui tabel

Tabel 02 Hasil Belajar Siklus I

\begin{tabular}{clcccc}
\hline \multirow{2}{*}{ No. } & \multicolumn{2}{c}{$\begin{array}{c}\text { Ketuntasan Belajar } \\
(\text { KKM=70) }\end{array}$} & \multicolumn{2}{c}{ Bhs. Indonesia } & \multicolumn{2}{c}{ IPA } \\
& & (f) & (\%) & (f) & (\%) \\
\hline 1. & Tuntas & 23 & $76,7 \%$ & 22 & $73,3 \%$ \\
2. & Tidak Tuntas & 7 & $23,3 \%$ & 8 & $26,7 \%$ \\
\hline & Jumlah & $\mathbf{3 0}$ & $\mathbf{1 0 0 \%}$ & $\mathbf{3 0}$ & $\mathbf{1 0 0 \%}$ \\
\hline
\end{tabular}

Dari tabel 02 di atas dapat diketahui bahwa hasil belajar siklus I untuk KD 3.9 terdapat 23 siswa yang termasuk dalam kriteria tuntas dengan persentase $76,7 \%$ dan sisanya sebanyak 7 siswa 
yang masih belum tuntas dengan persentase 23,3\% dari seluruh siswa. Kemudian untuk KD 3.4 terdapat 22 siwa dengan persentase $73,3 \%$ sudah tuntas dan sisanya sebanyak 8 siswa dengan persentase $26,7 \%$ masih belum tuntas. Dari data di atas menunjukan dalam kegiatan siklus I sudah mengalami peningkatan dalam ketuntasan hasil belajar. Untuk lebih jelasnya dapat dilihat pada diagram berikut:

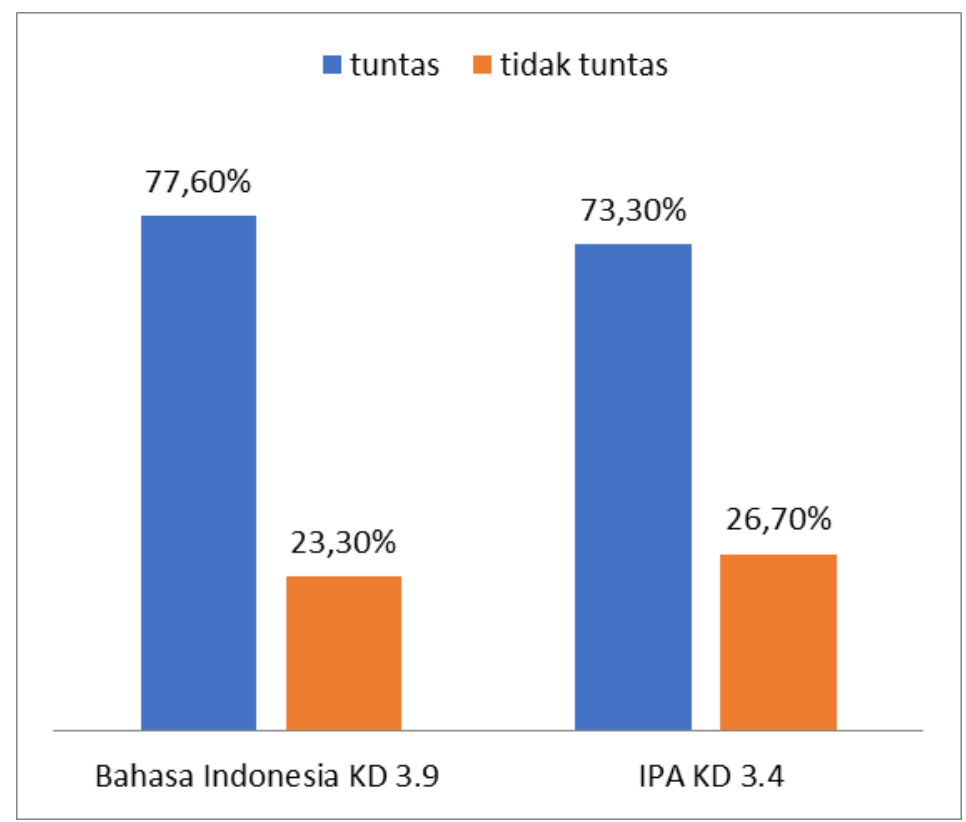

Gambar 02 Diagram Hasil Belajar Siklus I

Berdasarkan gambar diagram 02 di atas dapat dijelaskan bahwa ketuntasan hasil belajar dengan menerapkan model pembelajaran kooperatif tipe Jigsaw berbantu media gambar telah terbukti meningkatkan hasil belajar siswa.

Berdasarkan dari kegiatan penelitian yang dilakukan di SD Negeri Dukuh 2 Salatiga, khususnya siswa kelas IV dengan menerapkan model pembelajaran kooperatif tipe Jigsaw berbantu media gambar, maka diperoleh data yang signifikan. Adapun hasil penilaian presentasi kelompok pada siklus II yang dapat dilihat pada tabel berikut:

Tabel 03 Hasil Penilaian Presentasi Siklus II

\begin{tabular}{lcc}
\hline \multicolumn{1}{c}{ Aspek } & Rata-rata (\%) & Kriteria \\
\hline Intonasi & $80 \%$ & Baik \\
Bahasa & $85 \%$ & Sangat Baik \\
Volume Suara & $80 \%$ & Baik \\
\hline
\end{tabular}

Berdasarkan tabel 03 di atas dapat dilihat hasil penilaian presentasi hasil diskusi kelompok pada siklus II diketahui bahwa rata-rata intonasi siswa sebesar $80 \%$ dengan kriteria baik, rata-rata bahasa siswa sebesar $85 \%$ dengan kriteria sangat baik, serta rata-rata volume suara siswa sebesar 80\% dengan kriteria baik. Hasil penilaian presentasi hasil diskusi kelompok pada siklus II ini juga dapat disajikan dalam bentuk diagram yang dapat dilihat pada gambar 03 berikut: 


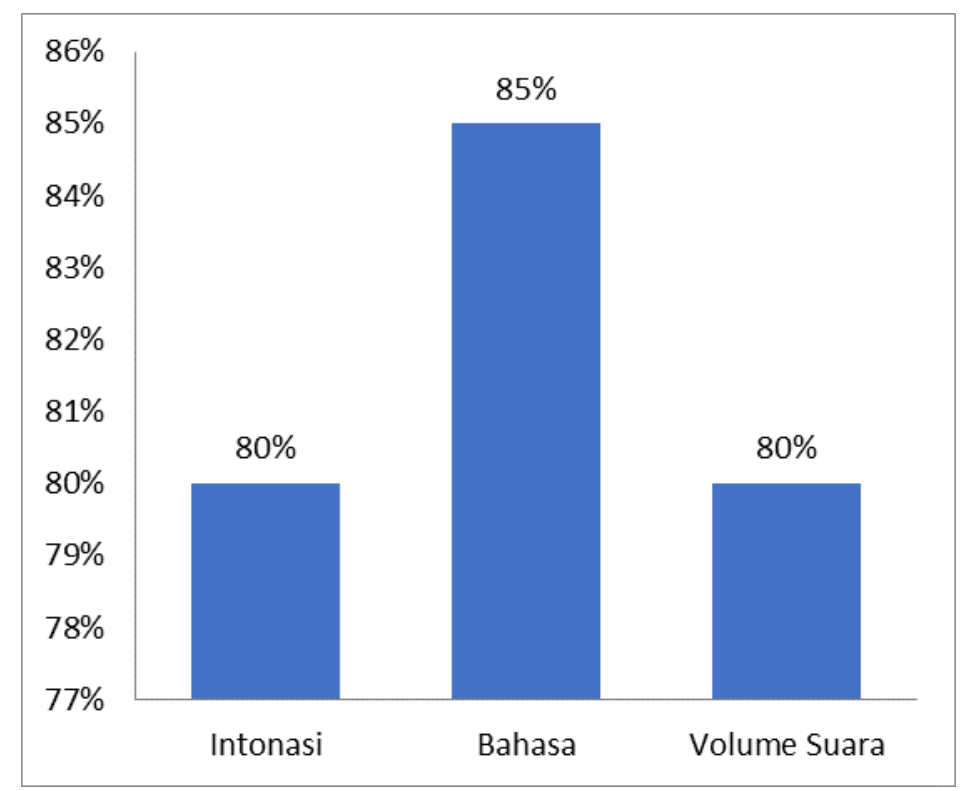

Gambar 03 Diagram Hasil Penilaian Presentasi Kelompok Siklus II berikut:

Kemudian untuk hasil belajar pada aspek pengetahuan juga dapat dilihat melalui tabel

Tabel 04 Hasil Belajar Siklus II

\begin{tabular}{|c|c|c|c|c|c|}
\hline \multirow{2}{*}{ No. } & \multirow{2}{*}{$\begin{array}{c}\text { Ketuntasan Belajar } \\
(\mathrm{KKM}=70)\end{array}$} & \multicolumn{2}{|c|}{ Bhs. Indonesia (KD 3.9) } & \multicolumn{2}{|c|}{$\begin{array}{c}\text { IPA } \\
\text { (KD 3.4) }\end{array}$} \\
\hline & & (f) & $(\%)$ & (f) & (\%) \\
\hline 1. & Tuntas & 27 & $90 \%$ & 25 & $83,3 \%$ \\
\hline 2. & Tidak Tuntas & 3 & $10 \%$ & 5 & $16,7 \%$ \\
\hline & Jumlah & 30 & $100 \%$ & 30 & $100 \%$ \\
\hline
\end{tabular}

Dari tabel di atas dapat diketahui bahwa hasil belajar siklus II untuk KD 3.9 terdapat 27 siswa tuntas dengan persentase $90 \%$ dan sisanya sebanyak 3 siswa masih belum tuntas dengan persentase 10\%. Kemudian untuk KD 3.4 terdapat 25 siswa tuntas dengan persentase 83,3\% dan sisanya terdapat 5 siswa belum tuntas dengan persentase 16,7\%. Peningkatan hasil belajar lebih terlihat untuk siklus II ini disbanding dengan siklus I. Ketuntasan hasil belajar siklus II dapat dilihat pada diagram dibawah ini:

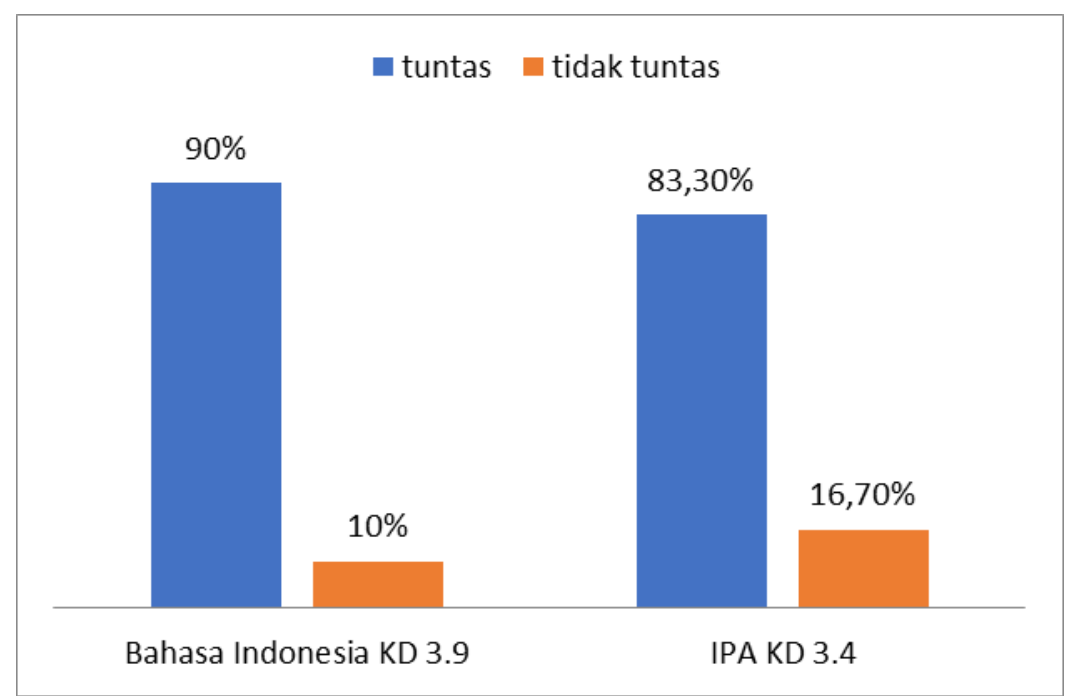

Gambar 04 Diagram Hasil Belajar Siklus II 
Berdasarkan gambar diagram $04 \mathrm{di}$ atas diketahui bahwa ketuntasan belajar siswa mengalami peningkatan yang signifikan dari kegiatan pra siklus dan siklus I dengan menerapkan model pembelajaran kooperatif tipe Jigsaw berbantu media gambar.

Teknik observasi merupakan pengamatan terhadap objek yang akan diukur dengan menggunakan lembarpengamatan atau lembar observasi yangtelah disiapkan sebelumnya. Observasi (observation) atau pengamatan merupakan suatu teknik atau cara pengumpulan data dengan jalan mengadakan pengamatan terhadap kegiatan yang sedang berlangsung, (Sukmadinata, 2013:220).

Tes merupakan intrumen yang digunakan untutk mengumpulkan data dalam pengukuran hasil tindakan penelitian. Teknik ini digunakan oleh peneliti dalam menguji subjek untuk mendapatkan data tentang hasil belajar peserta didik, dengan menggunakan butir-butir soal atau instrument soal yang mengukur hasil belajar sesuai dengan bidang mata pelajaran yang diteliti.

Setelah melakukan kegiatan pra siklus, peneliti melakukan tindkan di siklus I. Dalam pelaksanaan siklus I, peneliti melakukan 3 tahapan pembelajaran meliputi perencanaan, pelaksanaan dan pengamatan, serta refleksi. Pada tahap perencanaan peneliti mengkoordinasi mengenai rencana tindakan dengan guru kelas. Kemudian menentukan kompetensi inti, kompetensi dasar serta indikator materi pelajaran yang akan diajarkan. Setelah itu menentukan waktu dan skenario langkah-langkah pembelajaran. Menyusun perangkat-perangkat pembelajaran, seperti silabus, Pelaksanaan Pembelajaran (RPP), lembar kerja siswa, soal evaluasi, serta lembar penilaian serta menyusun instrumen penelitian berupa lembar observasi pelaksanaan pembelajaran model kooperatif tipe Jigsaw berbantuan media gambar terhadap guru dan siswa. Setelah semua sudah siap peneliti menyampaikan rencana pelaksanaan kegiatan kepada guru kelas IV SD Negeri Dukuh 2 Salatiga.

Berikut hasil pengumpulan data lembar observasi aktivitas guru dan siswa dalam kegiatan pembelajaran dengan menerapkan model pembelajaran Kooperatif tipe Jigsaw berbantu media gambar pada siklus I dan siklus II:

Berikut hasil pengumpulan data yang diperoleh dari pra siklus dan hasil tes siswa untuk mengetahui hasil belajar siswa setelah diterapkannya model pembelajaran Kooperatif tipe Jigsaw berbantu media gambar pada siklus I dan siklus II. Hasil data yang diperoleh dapat dilihat melalui perbandingan data pada tabel berikut:

Tabel 05 Perbandingan hasil belajar pra siklus, siklus I dan siklus II

\begin{tabular}{|c|c|c|c|c|c|c|c|c|c|c|c|c|c|}
\hline \multirow{3}{*}{ No. } & \multirow{3}{*}{$\begin{array}{c}\text { Ketuntasan } \\
\text { KKM } \geq 70\end{array}$} & \multicolumn{4}{|c|}{ Pra Siklus } & \multicolumn{4}{|c|}{ Siklus I } & \multicolumn{4}{|c|}{ Siklus II } \\
\hline & & \multicolumn{2}{|c|}{$\begin{array}{l}\text { Bahasa } \\
\text { Indonesia } \\
\text { (KD 3.9) }\end{array}$} & \multicolumn{2}{|c|}{$\begin{array}{c}\text { IPA } \\
\text { (KD 3.4) }\end{array}$} & \multicolumn{2}{|c|}{$\begin{array}{l}\text { Bahasa } \\
\text { Indonesia } \\
\text { (KD 3.9) }\end{array}$} & \multicolumn{2}{|c|}{$\begin{array}{c}\text { IPA } \\
\text { (KD 3.4) }\end{array}$} & \multicolumn{2}{|c|}{$\begin{array}{l}\text { Bahasa } \\
\text { Indonesia } \\
\text { (KD 3.9) }\end{array}$} & \multicolumn{2}{|c|}{$\begin{array}{c}\text { IPA } \\
\text { (KD 3.4) }\end{array}$} \\
\hline & & (f) & $\%$ & (f) & $\%$ & (f) & $\%$ & (f) & $\%$ & (f) & $\%$ & (f) & $\%$ \\
\hline 1 & Tuntas & 14 & $\begin{array}{c}46,7 \\
\%\end{array}$ & 11 & $36,7 \%$ & 23 & $76,7 \%$ & 22 & $73,3 \%$ & 27 & $90 \%$ & 25 & $83,3 \%$ \\
\hline 2 & $\begin{array}{l}\text { Tidak } \\
\text { Tuntas }\end{array}$ & 16 & $\begin{array}{c}53,3 \\
\%\end{array}$ & 19 & $63,3 \%$ & 7 & $23,3 \%$ & 8 & $26,7 \%$ & 3 & $10 \%$ & 5 & $16,7 \%$ \\
\hline \multicolumn{2}{|c|}{ Jumlah } & 30 & $100 \%$ & 30 & $100 \%$ & 30 & $100 \%$ & 30 & $100 \%$ & 30 & $100 \%$ & 30 & $100 \%$ \\
\hline \multicolumn{2}{|c|}{ Rata-Rata } & $\begin{array}{c}68, \\
6\end{array}$ & & 67,9 & & 74,2 & & 73,2 & & 78,6 & & 76 & \\
\hline \multicolumn{2}{|c|}{$\begin{array}{l}\text { Persentase } \\
\text { Ketuntasan }\end{array}$} & $46,7 \%$ & & $\begin{array}{c}36,7 \\
\%\end{array}$ & & $76,7 \%$ & & $73,3 \%$ & & $90 \%$ & & $83,3 \%$ & \\
\hline \multicolumn{2}{|c|}{$\begin{array}{l}\text { Persentase } \\
\text { TidakTuntas }\end{array}$} & $53,3 \%$ & & $\begin{array}{c}63,3 \\
\%\end{array}$ & & $23,3 \%$ & & $26,7 \%$ & & $10 \%$ & & $16,7 \%$ & \\
\hline \multicolumn{2}{|c|}{ Nilai Tertinggi } & 80 & & 80 & & 91 & & 84 & & 94 & & 88 & \\
\hline \multicolumn{2}{|c|}{ Nilai Terendah } & 55 & & 60 & & 55 & & 60 & & 65 & & 68 & \\
\hline
\end{tabular}

Tujuan dari penelitian ini adalah Untuk meningkatkan hasil belajar siswa kelas IV SD Negeri Dukuh 2 Salatiga melalui model pembelajaran kooperatif tipe Jigsaw berbantu media gambar pada tema 8 "Tempat Tinggalku".

Sebagai latar belakang untuk penelitian ini, peneliti melakukan kegiatan observasi pada pra siklus untuk mencari masalah yang akan diselesaikan. Berdasarkan hasil observasi yang dilakukan di kelas IV SD Negeri Dukuh II Kota Salatiga, hasil pembelajaran terbukti selalu kurang memuaskan. 
Hampir dari keseluruhan siswa, kurang dari 50\% siswa yang mancapai ketuntasan KKM 70. Selain itu banyak kendala yang dialami oleh siswa diantara siswa tidak nyaman atau tidak antusias dengan metode mengajar yang digunakan. Guru cenderung menggunakan metode ceramah, sehingga siswa hanya diam mendengarkan materi yang disampaikan guru, siswa kurang aktif, serta ada yang siswa yang cerita dan bermain-main sendiri saat proses pembelajaran berlangsung.

Berdasarkan permasalahan di atas yang telah dipaparkan, penulis sebagai peneliti hendak merancang penelitian yang berjudul "Upaya Peningkatan Hasil Belajar Melalui Model Pembelajaran Kooperatif Tipe Jigsaw Berbantu Media Gambar Siswa Kelas IV" sebagai upaya penyelesaian permasalahan yang terjadi. Setelah dilakukan penelitian diperoleh data dari kegiatan siklus I yaitu hasil belajar meningkat untuk KD 3.9 terdapat 23 siswa yang termasuk dalam kriteria tuntas dengan persentase $76,7 \%$ dan sisanya sebanyak 7 siswa yang masih belum tuntas dengan persentase 23,3\% dari seluruh siswa. Kemudian untuk KD 3.4 terdapat 22 siwa dengan persentase $73,3 \%$ sudah tuntas dan sisanya sebanyak 8 siswa dengan persentase $26,7 \%$ masih belum tuntas. Kemudian kembali meningkat pada hasil kegiatan siklus II yaitu untuk KD 3.9 terdapat 27 siswa tuntas dengan persentase $90 \%$ dan sisanya sebanyak 3 siswa masih belum tuntas dengan persentase 10\%. Kemudian untuk KD 3.4 terdapat 25 siswa tuntas dengan persentase $83,3 \%$ dan sisanya terdapat 5 siswa belum tuntas dengan persentase $16,7 \%$. \%. Dengan demikian peneliti dapat menyimpulkan bahwa penelitian yang dilakukan untuk peningkatan hasil belajar siswa kelas IV SD Negeri Dukuh 2 Salatiga tema 8 "Tempat Tinggalku" dengan menerapkan model pembelajaran kooperatif tipe Jigsaw berbantu media gambar terbukti adanya dapat meningkatkan hasil belajar dari siswa.

\section{Simpulan dan Saran}

Berdasarkan hasil penelitian dan pembahasan yang telah diuraikan sebelumnya, yang awalnya hampir dari keseluruhan siswa, kurang dari 50\% siswa yang mancapai ketuntasan KKM 70 dan kemudian mengalami peningkatan setelah dilakukan beberapa siklus dengan menerapkan model pembelajaran kooperatif tipe Jigsaw berbantu media gambar pada pemebelajaran tema 8 "Tempat Tinggalku". Hal ini menjadi bukti bahwa penelitian yang bertujuan untuk meningkatan hasil belajar siswa kelas IV SD Negeri Dukuh 2 Salatiga tema 8 "Tempat Tinggalku" sangat efektif berhasil.

Berdasarkan simpulan maka peneliti dapat mengemukakan beberapa saran terkait hasil penelitian kepada; 1) Bagi guru yaitu dapat mengupayakan peningkatkan hasil belajar siswa dengan menerapkan model pembelajaran kooperatif tipe Jigsaw berbantu media gambar di dalam proses pembelajaran. 2) Bagi siswa yaitu siswa akan lebih aktif didalam proses pembelajaran. Siswa akan merasa lebih puas dan senang dengan meningkatnya hasil belajar yang didapatkan. Pengalaman baru akan didapatkan siswa setelah melakukan proses pembelajaran.

\section{Daftar Rujukan}

Aqib, Zainal. Penelitian Tindakan Kelas, (Bandung: Yrama Widya, 2006), hal. 22

Arief S, Sadiman. Media pendidikan: Pengertian, Pengembangan dan Pemanfaatannya. ( Jakarta: Rajawali Pers. 2009). hlm.29-33

Arikunto, Suharsimi. Dasar-Dasar Evaluasi Pendidikan. (Jakarta: Bumi Aksara, 2010). hlm. 274.

Asyari. Muslichah. 2006a. Penerapan Sains Teknologi Masyarakat Dalam Pembelajaran Sainis di SD. Depdiknas Dirjen Dikti Direktorat Ketenagaan. Hal.11

Cecep Kusnandi, Bambang Sujtipto. Media Pembelajaran Manual dan Digital. (Bogor: Ghalia Indonesia. 2013). hlm. 41-42

Huda, Miftahul. (2012). Cooperative Learning Metode, Teknik, Struktur dan Model Terapan. Yogyakarta: Ppustaka Pelajar.

Isjoni. (2010). Pembelajaran Kooperatif Meningkatkan Kecerdasan Komuniasi Antar Peserta Didik. Yogyakarta: Pustaka Belajar. 
Kemendikbud. 2013.Kerangka Dasar Kurikulum 2013.Kementerian Pendidikandan Kebudayaan Direktorat Jenderal Pendidikan Dasar. Jakarta

Kunandar. 2013. Langkah Mudah Penelitian Tindakan Kelas Sebagai Pengembangan Profesi. PT. Raja Grafindo Persada.Jakarta.

Mulyati. 2015. Terampil Berbahasa Indonesia Untuk Perguruan Tinggi. Jakarta: Prenadamedia Group.

Prastowo, Andi. (2013). Panduan Kreatif Membuat Bahan AjarInovatif. Yogyakarta: Diva Press.

Richard E Mayer. Multimedia Prinsip-prinsip dan Aplikasi. (Yogyakarta: Pustaka pelajar, 2009). hlm. 95-99

Rusman. 2013. Model-Model Pembelajaran Mengembangkan Profesionalisme Guru. Jakarta. PT Rajagrafindo Persada.

Rusman. 2015. Model-model Pembelajaran Mengembangkan Profesional Guru.Rajawali Pers.Jakarta.

Sukmadinata, Nana Syaodih. 2013.Metode Penelitian Pendidikan. Bandung: PT Remaja Rosdakarya, hal 220 .

Sulistyanto, H, dan Wiyono, E. (2008) Ilmu Pengetahuan Alam: Untuk SD/MI Kelas 5. Jakarta: Pusat Perbukuan, Departemen Pendidikan Nasional.

Suprijono. 2015. Cooperative Learning.Pustaka Belajar. Yogyakarta.

Triyanto. 2011. Desain Pengembangan Pembelajaran Temati Bagi Anak Usia Dini TK/RA \& Anak Usia Kelas Awal SD/MI. Kencana Prenada Media Group. Jakarta. 